\title{
SEASAT geoid anomalies and the Macquarie Ridge complex
}

\author{
Larry Ruff * \\ Department of Geological Sciences, University of Michigan, Ann Arbor, MI 48109 (U.S.A.) \\ Anny Cazenave
}

CNES-GRGS, 18 Ave. Edouard Belin, Toulouse, 31055 (France)

(Received August 10, 1984; revision accepted September 5, 1984)

Ruff, L. and Cazenave, A., 1985. SEASAT geoid anomalies and the Macquarie Ridge complex. Phys. Earth Planet. Inter., 38: 59-69.

\begin{abstract}
The seismically active Macquarie Ridge complex forms the Pacific-India plate boundary between New Zealand and the Pacific-Antarctic spreading center. The Late Cenozoic deformation of New Zealand and focal mechanisms of recent large earthquakes in the Macquarie Ridge complex appear consistent with the current plate tectonic models. These models predict a combination of strike-slip and convergent motion in the northern Macquarie Ridge, and strike-slip motion in the southern part. The Hjort trench is the southernmost expression of the Macquarie Ridge complex. Regional considerations of the magnetic lineations imply that some oceanic crust may have been consumed at the Hjort trench. Although this arcuate trench seems inconsistent with the predicted strike-slip setting, a deep trough also occurs in the Romanche fracture zone.

Geoid anomalies observed over spreading ridges, subduction zones, and fracture zones are different. Therefore, geoid anomalies may be diagnostic of plate boundary type. We use SEASAT data to examine the Macquarie Ridge complex and find that the geoid anomalies for the northern Hjort trench region are different from the geoid anomalies for the Romanche trough. The Hjort trench region is characterized by an oblique subduction zone geoid anomaly, e.g., the Aleutian-Komandorski region. Also, limited first-motion data for the large 1924 earthquake that occurred in the northern Hjort trench suggest a thrust focal mechanism. We conclude that subduction is occurring at the Hjort trench. The existence of active subduction in this area implies that young oceanic lithosphere can subduct beneath older oceanic lithosphere.
\end{abstract}

\section{Introduction}

Geoid anomalies over different plate boundary types are strikingly different. In this paper, we are not concerned with the modeling of geoid anomalies. Instead, we simply use the geoid anomalies along the Macquarie Ridge complex to qualitatively determine the nature of this perplexing plate boundary. We first describe the tectonic problem, and then compare the SEASAT geoid profiles from the Macquarie Ridge complex to those from

* Shell Faculty Fellow. fracture and subduction zones. Our results indicate that the comparison of short-wavelength geoid anomalies can provide tectonic information.

\section{Tectonic setting}

The Macquarie Ridge complex lies between South Island, New Zealand and the Pacific-Antarctic spreading center. The high level of seismic activity indicates that the Macquarie Ridge complex is the southernmost segment of the plate boundary between the Pacific and India plates. 


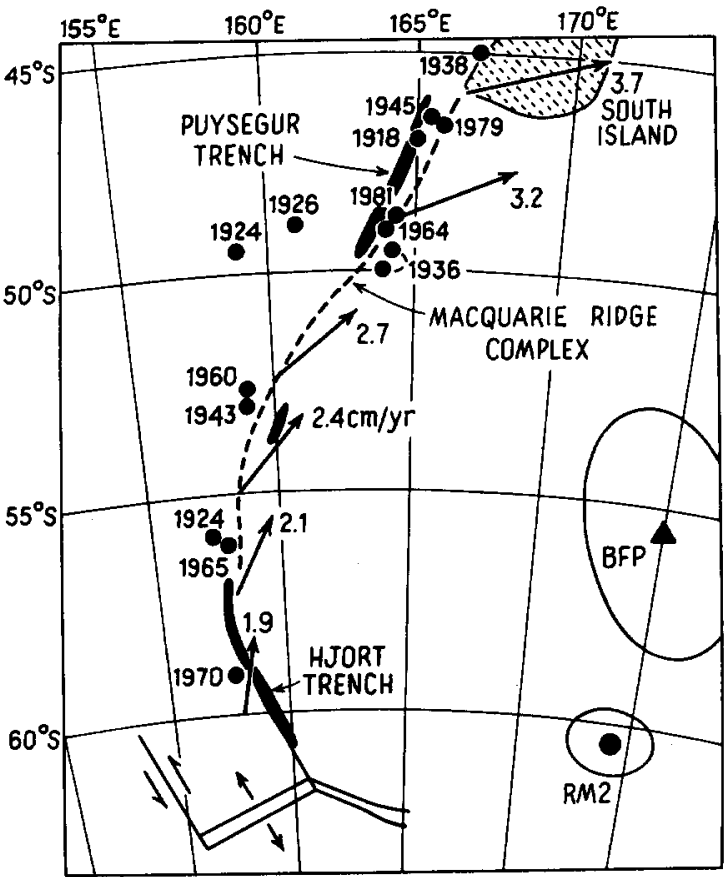

Fig. 1. Seismicity and tectonics of the Macquarie Ridge complex. Earthquakes larger than magnitude $>7$ are plotted as solid circles with the year of their occurrence. The poles of rotation between the India and Pacific plates are the best fitting pole (BFP) between these two plates, and the globally derived pole (RM2). Both poles and their error ellipses are taken from Minster and Jordan (1978). The vectors along the Macquarie Ridge show the motion of the India plate relative to the Pacific plate (based on the RM2 pole, velocity in $\mathrm{cm} \mathrm{y}^{-1}$ ). The Macquarie Ridge is schematically plotted as the dashed line.

Owing to uncertainties in the relative motion between the Pacific and Indian plates and a complicated bathymetry, the Macquarie Ridge complex has been described as a: (1) spreading center, (2) fracture zone, (3) subduction zone, and (4) some combination of the above. The relative plate motions along the Macquarie Ridge complex are sensitive to the location of the Pacific-Indian rotation pole since the pole is located close to the Macquarie Ridge. The RM2 rotation pole from the study of Minster and Jordan (1978) is plotted in Fig. 1 . Note that the relative motions predicted by the RM2 pole change from nearly pure strikeslip in the southern part to a combination of strike-slip and convergence in the northern part of the ridge complex. An analysis of South Island triangulation data by Walcott (1978) supported the location of the RM2 rotation pole. Also, the slip vector azimuths of two earthquakes studied by Banghar and Sykes (1969) are within $35^{\circ}$ of the RM2 relative motions. Four large earthquakes have occurred in the Macquarie Ridge complex since the study of Banghar and Sykes (1969). These recent earthquakes have been studied by Ruff et al. (1982) and, though there are complications, the focal mechanisms are in basic agreement with the RM2 motions. Hence, the RM2 rotation pole appears to be a good representation of the presentday relative motions in New Zealand and the Macquarie Ridge complex.

The plate tectonic reconstruction of Molnar et al. (1975) indicated that a large wedge of material including the entire Macquarie Ridge complex has formed by spreading activity since the Oligocene (38 Ma). In a later study, Walcott (1978) showed the Pacific-India rotation pole migrating south since the Oligocene. The observations of Scholz et al. (1973) also implied a southward migration of the rotation pole, particularly since the Miocene. Therefore, the available evidence indicates that the Macquarie Ridge complex was previously characterized by strike-slip and spreading motions, and that convergence is a recent activity.

The above cited evidence presents a consistent picture of the recent tectonics in this region. However, not all of the bathymetric features are readily explained by this tectonic framework. Our main concern here is with the trenches that are part of the complex. The intermediate-depth earthquakes beneath the southwestern corner of South Island are consistent with the formation of a post-Miocene subduction zone off the southwestern coast of South Island (as summarized by Scholz et al., 1973). Under the assumption that the rotation pole has migrated south since the Miocene, the relative convergence rate has increased in the northernmost Macquarie Ridge complex in the past few million years. The Puysegur trench (between $46^{\circ} \mathrm{S}$ and $49^{\circ} \mathrm{S}$ ) can then be interpreted as a recent convergent feature. The lack of a volcanic, arc can be attributed to the recent initiation of subduction. The above explanation does not apply to the Hjort trench (between $56^{\circ} \mathrm{S}$ and $60^{\circ} \mathrm{S}$ ). As seen in Fig. 1, the present-day plate motions along the Hjort 
trench are predominantly strike-slip, and we expect the Late Cenozoic motions to be a combination of strike-slip and spreading. Is the Hjort trench consistent with a strike-slip plate boundary? Global bathymetric maps show that many fracture zones are delineated by troughs, but these troughs are rarely $6 \mathrm{~km}$ deep as is the Hjort trench. The Romanche fracture zone is probably the best fracture zone analogue for the Hjort trench, as the Romanche trough obtains a depth of $6 \mathrm{~km}$ for a distance of $600 \mathrm{~km}$. Hayes et al. (1972) showed one gravity profile that crosses the Hjort trench at

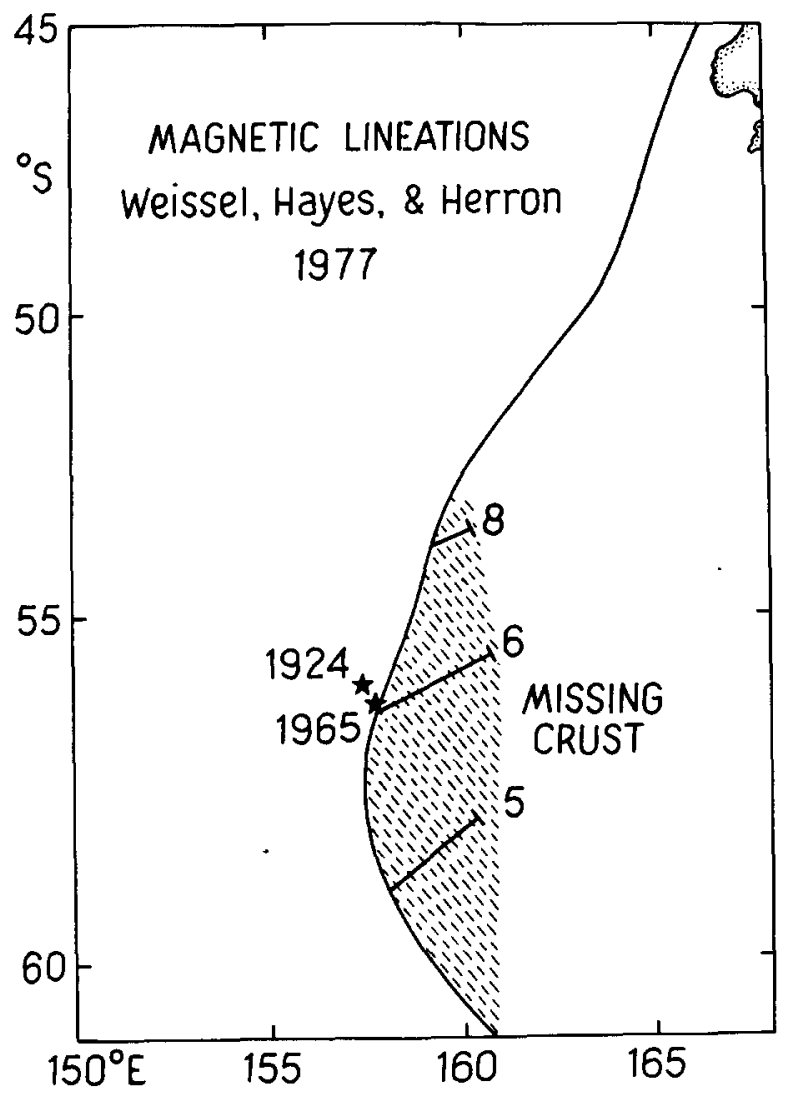

Fig. 2. Missing crust in the Hjort trench region. Weissel et al. (1977) noted that the lengths of magnetic lineations did not match across the spreading ridge that intersects the Hjort trench. The bars show the missing segments of magnetic lineations $\sharp 5,6$, and 8 . The solid line shows the approximate location of the Macquarie Ridge complex. One interpretation of the shortened magnetic lineations is that the missing crust (stippled) has been subducted. The stars show the epicenters for the 1924 and 1965 earthquakes. $59^{\circ} \mathrm{S}$. They commented that the gravity profile is similar to profiles observed over fracture zone troughs.

On the other hand, Weissel et al. (1977) presented some evidence that suggests recent convergence in the Hjort trench region. This evidence is based on magnetic lineations. The lineation length, measured parallel to the spreading ridge segment, should be the same for lineations of the same age on either side of the ridge segment. Weissel et al. (1977) noted that the magnetic lineations of the crust between the Hjort trench and the Balleny fracture zone are shorter than their corresponding lineation south of the ridge segment. Hence, there is some missing crust as Fig. 2 shows. Weissel et al. (1977) offered two explanations for the missing crust: (1) the Pacific-India plate boundary jumped westward to the present location at the Hjort trench; and (2) the missing crust has been subducted at the Hjort trench. This latter interpretation implies that up to $200 \mathrm{~km}$ of young oceanic lithosphere has subducted beneath older oceanic lithosphere, with a minimum convergence rate of 1-2 $\mathrm{cm} \mathrm{y}^{-1}$ along the Hjort trench.

To summarize the tectonic setting of the Hjort trench; in favor of a strike-slip origin, the plate tectonic reconstructions show no convergence in the Hjort trench region, there is a fracture zone trough (Romanche) of the same extent as the Hjort trench, and two focal mechanisms show mostly strike-slip motion; and suggestive of a convergence origin, the shortened magnetic lineations. We wish to further investigate the nature of this plate boundary. Different tectonic elements produce different characteristic geoid anomalies, and the availability of SEASAT data now makes it feasible to examine the Hjort trench in more detail.

\section{Geoid anomalies and SEASAT}

Direct mapping of the ocean surface by radar altimetry satellites (Geos 3 and SEASAT) allows the investigation of geoid anomalies with a height of $10-30 \mathrm{~cm}$ and a horizontal extent of $100 \mathrm{~km}$ or less. The high accuracy and the global coverage of the altimeter data provide a new geophysical data 
set that can be used for systematic studies of the lateral density variation in the oceanic lithosphere. Detailed maps of the geoid contours derived from Geos 3 and SEASAT data clearly reveal the major features associated with plate tectonics; the geoid anomalies at deep-sea trenches are the most apparent. Individual altimeter profiles also show short-wavelength geoid highs correlated with seamounts and volcanic chains, and step-like geoid anomalies caused by fracture zones and continental margins. It appears that mid-ocean ridges give a weaker signal although ridges are detectable in a number of cases. Each type of tectonic feature causes a specific signature in the geoid, and the shape, amplitude and wavelength of the associated geoid anomaly contain information on the internal density structure as well as on the state of isostatic compensation.

Theoretical lithospheric geoid signatures have been derived by Haxby and Turcotte (1978) for the major tectonic features, on the assumption that they are isostatically compensated. These authors showed that "isostatic" geoid anomalies can be directly related to the vertical dipole moment of the local density distribution and, on the basis of accepted models, they derived predicted anomalies over mid-ocean ridges and continental margins in remarkable agreement with observed anomalies. The observed shape of the geoid has been used as a constraint on oceanic lithosphere cooling models (Sandwell and Schubert, 1980), and on the magnitude of the plate driving force (Parsons and Richter, 1980). Over fracture zones (FZ), geoid anomalies show a step-like signal of $1-3 \mathrm{~m}$ amplitude, downward from the young, shallow side to the old, deep side of the FZ. This offset in the geoid is due to the contrast in plate thickness and density structure as predicted by thermal models. Several analyses of FZ geoid anomalies have been conducted to estimate the parameters entering into the models of lithospheric cooling (e.g., Crough, 1979; Detrick, 1981; Sandwell and Schubert, 1982; Cazenave et al., 1983).

Deep-sea trenches also give rise to a characteristic geoid signature. There is a narrow geoid minimum of $5-20 \mathrm{~m}$ amplitude and $100-400 \mathrm{~km}$ in width, directly over the trench axis. From the trench to the landward side, there is a geoid high coinciding generally with the island arc when present. Superimposed on this short wavelength variation, one observes a broad positive anomaly in the geoid, starting $1000-3000 \mathrm{~km}$ away from the trench axis on the side of the subducting plate. The maximum value of the long-wavelength geoid high occurs in the vicinity of the trench and the typical amplitude varies from $10 \mathrm{~m}$ to a few tens of meters. Although differing in their detailed expression, all known subduction zones produce geoid anomalies with the above characteristics. Moreover, the geoid signature of a subduction zone is quite distinct from those caused by other tectonic features. Several studies have attempted to explain the subduction zone geoid signal (e.g., Davies, 1981; Mc Adoo, 1981). The interpretations differ in some details, but there is a general agreement to ascribe the broad positive high to the cold, dense subducting slab penetrating the asthenosphere, while the short wavelength geoid low results from the flexure of the plate at the trench axis. Davies (1981) showed that regional compensation of the subducting plate can explain the amplitude of the broad positive geoid high.

Given the characteristic geoid anomalies of the different tectonic features, altimeter-derived geoid anomalies can be used to discover previously unnoticed tectonic features. For example, numerous uncharted seamounts have been detected with SEASAT data (e.g., Lazarewicz and Schwank, 1982; Sandwell, 1984), while Sailor and Okal (1983), also using SEASAT data, discovered a fracture zone in the central Pacific. In our application, we use geoid profiles to test whether the two main troughs in the Macquarie Ridge complex have a fracture zone or subduction zone character.

\subsection{Romanche fracture zone}

One of the major transform faults in the Atlantic spreading ridge system is the Romanche fracture zone; the spreading ridge segments are offset $\sim 1000 \mathrm{~km}$ across this fracture zone. Along the active part of the transform plate boundary, there is a trough that is similar to the Hjort trench in both depth and horizontal extent (see Fig. 3). The Romanche trough demonstrates that it is possible 


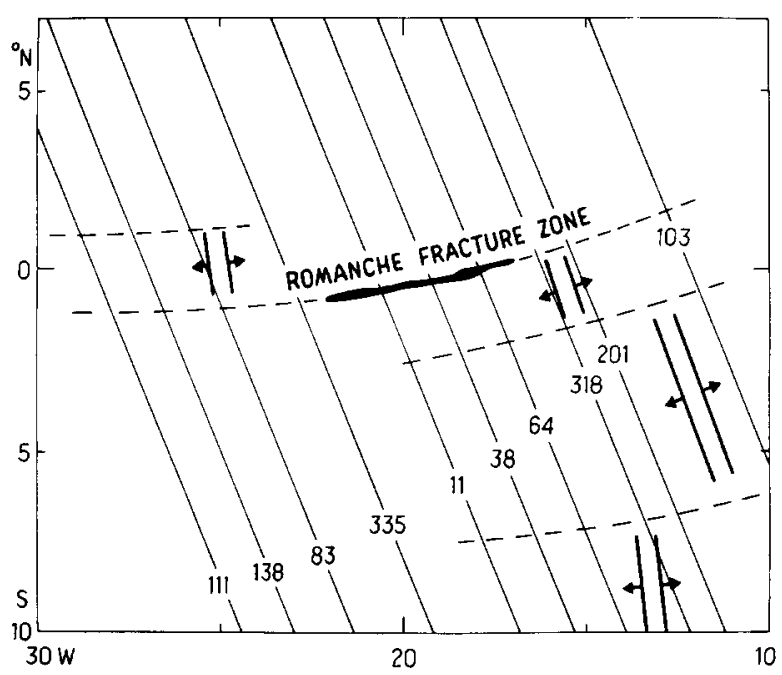

Fig. 3. Index map of SEASAT profiles across the Romanche fracture zone. The numbered lines show the satellite tracks. The shaded portion of the Romanche trough is deeper than $6 \mathrm{~km}$. Fracture zones are depicted by dashed lines, the spreading ridge segments are also shown.

to obtain a $6 \mathrm{~km}$ deep trough along a strike-slip plate boundary. Since the Macquarie Ridge complex has served as a strike-slip plate boundary, perhaps the Hjort trench has the same tectonic origin as the Romanche trough. The contrast in lithosphere age is greater across the Hjort trench than across the Romanche trough, but we might expect the short-wavelength geoid anomalies over the troughs to be similar. Figure 4 shows the geoid profiles across the Romanche fracture zone. Note the characteristic FZ geoid profile, i.e., a step increase of $5 \mathrm{~m}$ or less when crossing to the younger lithosphere. This step-like character disappears at the Romanche trough (profiles [11], [38], and [64]), and there is no pronounced short-wavelength geoid anomaly associated with the trough. Thus, the Romanche trough geoid low is significantly less than $5 \mathrm{~m}$.

\subsection{Aleutian-Komandorski Region}

The Pacific plate subducts beneath the North America plate along the Aleutian trench. The Aleutian island arc system displays most of the typical subduction zone features: a well-developed

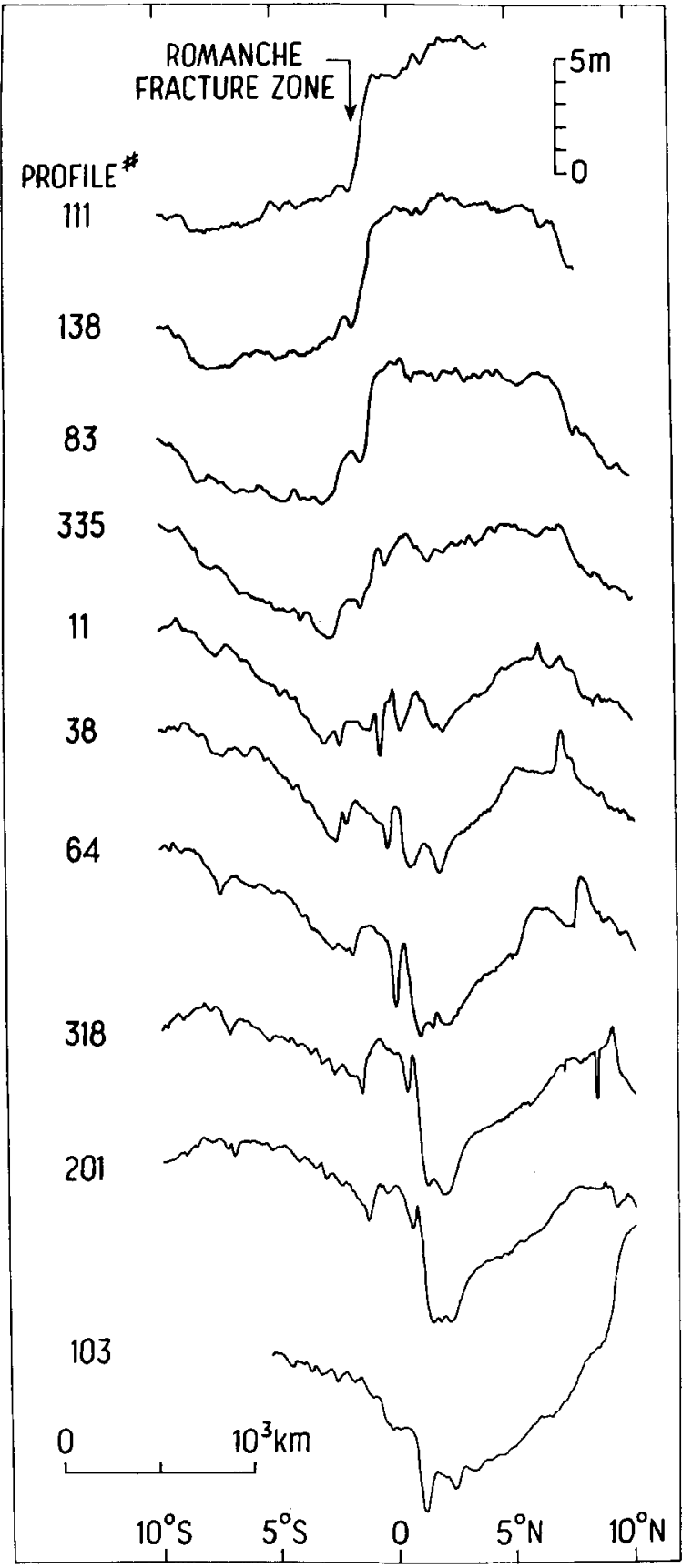

Fig. 4. Geoid profiles across the Romanche fracture zone. Profile numbers are the same as in Fig. 3. The profiles are plotted such that south to north corresponds with left to right. Note the $5 \mathrm{~m}$ step in the geoid height across the fracture zone. This step is best developed where the lithosphere age contrast across the fracture zone is largest. 


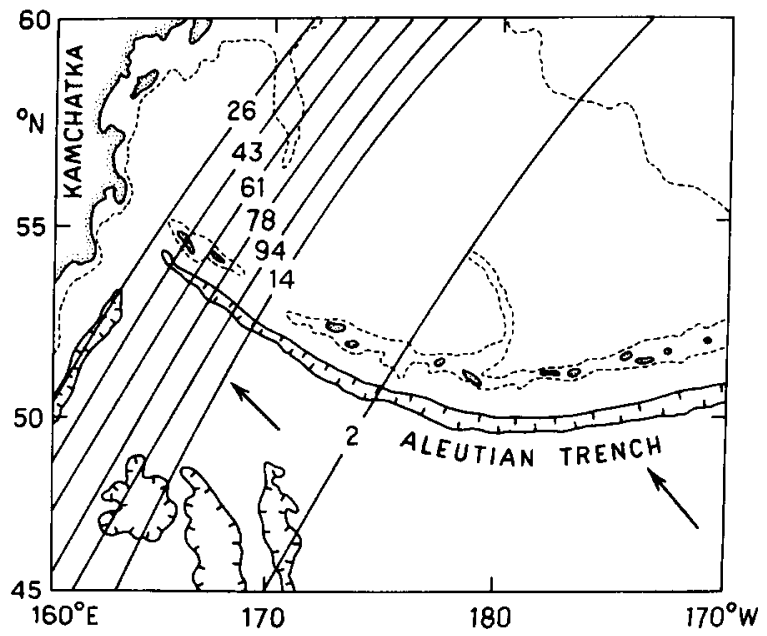

Fig. 5. Index map of SEASAT profiles in the Aleutian-Komandorski region. Land areas are shown by solid lines and dot pattern. The Aleutian trench and other troughs are delineated by the $6 \mathrm{~km}$ depth contours. The $1 \mathrm{~km}$ depth contour is plotted with a dashed line. Note the break in the island arc platform between the central Aleutians and Komandorski island. The two arrows show the motion of the Pacific plate relative to the North American plate.

Benioff zone with intermediate depth seismicity, an arcuate, deep trench, an active chain of volcanoes, and large underthrusting earthquakes. The curved nature of the Aleutian island arc system results in a marked change in the plate boundary type in the western half of the system. As Fig. 5 shows, the relative plate motion changes from mostly convergence in the central Aleutians to nearly pure strike-slip at Komandorski Island, the western endpoint of the Aleutian system. The Emperor seamount chain intersects the subduction zone at the kink between the Aleutian and Kamchatka trenches. There is a broad bathymetric and geoid high associated with the Emperor seamount chain (Watts, 1979).

The Aleutian-Komandorski region provides an excellent example of the transition from pure subduction through oblique subduction to strike-slip along an island arc system. In addition, the Emperor seamount chain gives the oceanic lithosphere in the Komandorski region a "younger appearance", similar to the Hjort trench geometry. It is interesting to note that when proceeding from

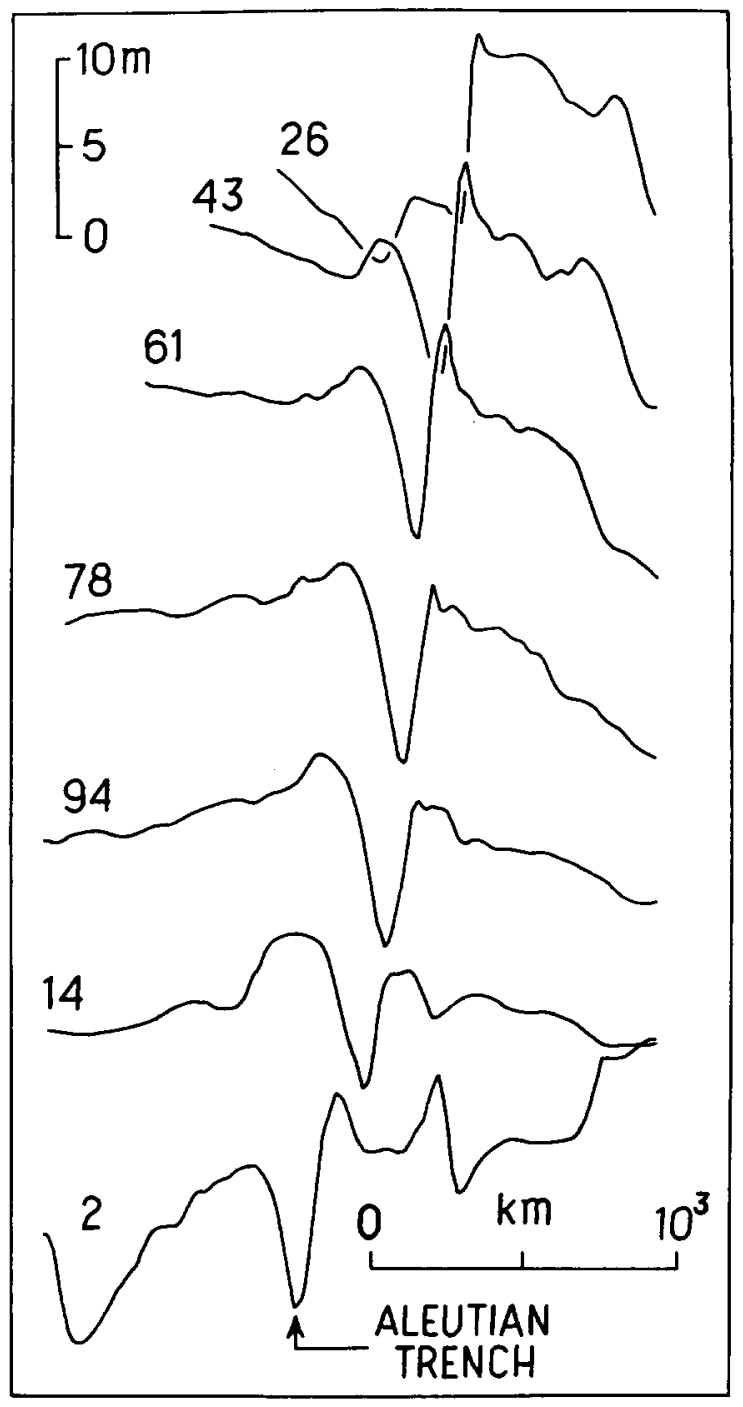

Fig. 6. Geoid profiles across the Aleutian trench. See Fig. 5 for location of the numbered profiles. The profiles are plotted with left to right corresponding with south to north. The profiles are aligned with $60^{\circ} \mathrm{N}$ at the right-hand edge of the profiles. Profile [2] shows the characteristic subduction zone geoid anomaly.

the central Aleutians to Komandorski Island, the intermediate-depth earthquakes disappear and the overall level of shallow seismicity diminishes. Figure 6 shows the geoid profiles across this transition. Profile [2] crosses the rupture zone of the great 1965 earthquake (see Sykes et al., 1981); this zone includes the western limit of active volcanoes 
and intermediate-depth earthquakes. Profile [2] presents a typical subduction zone geoid anomaly: a broad geoid high with a short-wavelength geoid low over the trench and high over the island arc with a peak-to-trough amplitude of $12 \mathrm{~m}$. The second peak in profile [2] is related to the Bowers Ridge, and the edge of the continental shelf is also prominent. The outer-rise geoid high in profiles [14] through [43] is associated with the Emperor seamount rise. Profiles [14] through [78] do not show the geoid peak related to the island arc as they cross a gap in the island arc system (see Fig. 5). Notice that profiles [61] and [43], which cross the Komandorski Island region, show the same peak-to-trough character as profile [2], though the broad geoid high is not apparent. Thus the shortwavelength geoid anomalies in a highly oblique subduction zone show the typical subduction zone character. While the short-wavelength geoid low over the Romanche trough is less than $5 \mathrm{~m}$, the geoid low associated with the Aleutian-Komandorski trench is $7-10 \mathrm{~m}$.

\subsection{Macquarie Ridge complex}

We have analyzed a number of SEASAT geoid profiles crossing the Macquarie Ridge complex. Figure 7 shows the satellite tracks superimposed on the simplified bathymetry of this region (see Mammericks et al., 1975). We have selected ascending (SE-NW) profiles that cross the Puysegur trench, the Macquarie Ridge and Hjort trench. We have also used six descending profiles which are nearly perpendicular to the Hjort trench in its extreme southern part. We have removed the long wavelengths $(>4000 \mathrm{~km}$ ) from the profiles.

Profiles [128] through [200] cross the Puysegur trench and show a small negative anomaly over the trench (Fig. 8). The negative anomaly of $3 \mathrm{~m}$ in profile [103] coincides with the maximum depth of the Puysegur trench $(-6 \mathrm{~km})$. This small geoid low is followed by a sharp geoid high over the bathymetric high. Notice that profile [200] crosses south of the deep part of the Puysegur trench and shows no geoid low. The strong positive signal at the eastern edge of these profiles is associated with the Campbell plateau. The character of the Puysegur trench profiles, i.e., a sharp geoid high

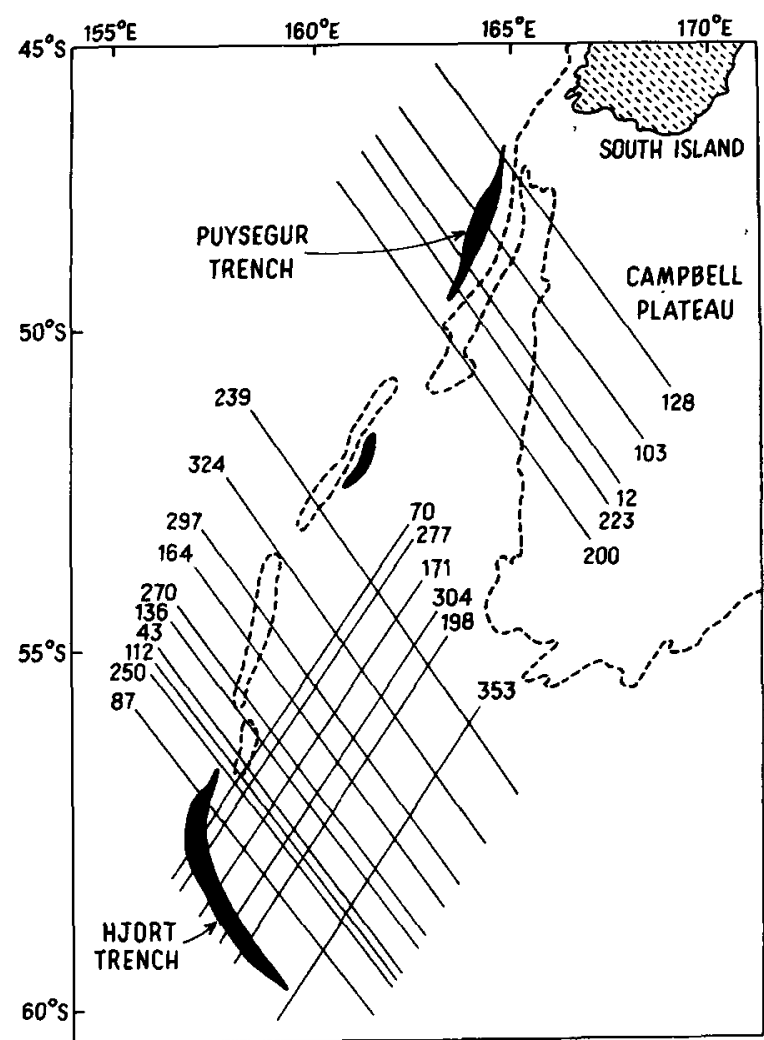

Fig. 7. Index map of SEASAT profiles in the Macquarie Ridge region. Numbers refer to the profile numbers in Figs. 8 and 9. The trenches are delineated by the 2600 fathom depth contour. The Campbell plateau and parts of the Macquarie Ridge are delineated by the 1000 fathom depth contour (contours taken from Mammericks et al., 1975).

flanked by a small geoid low, is unlike the basic character of the Romanche or Aleutian-Komandorski geoid anomalies. The Puysegur trench geoid anomaly does resemble the anomaly observed over the Gorringe Ridge, which may be a nascent subduction zone (see Souriau, 1984).

Figure 9 shows the geoid profiles that cross the central part of the Macquarie Ridge and the Hjort trench. These profiles are characterized by a smooth transition in the short-wavelength features; from a geoid high over the Macquarie Ridge, through a pronounced geoid low in the northern Hjort trench region, and finally to a geoid step in the southernmost profile.

The geoid signature of the Hjort trench is different from that of the Romanche trough, in par- 


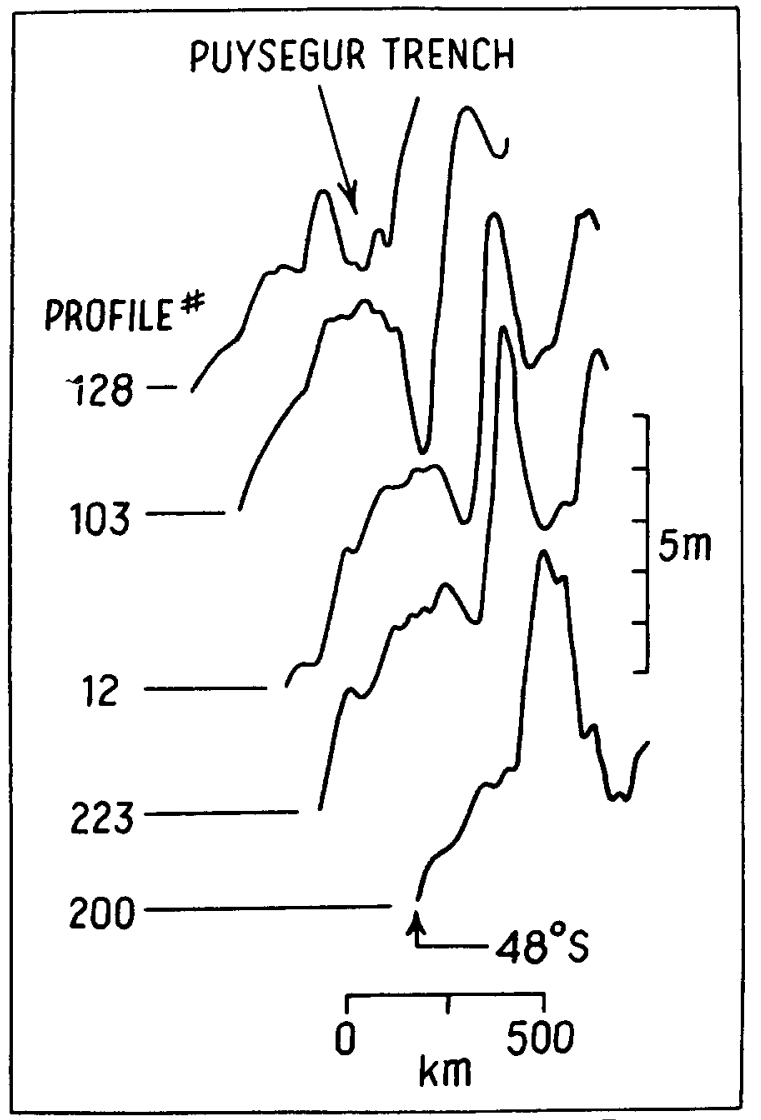

Fig. 8. SEASAT geoid height profiles across the Puysegur trench. Profile orientation is such that left to right corresponds with west to east. The profiles are aligned so that constant latitude plots as a vertical line; $48^{\circ} \mathrm{S}$ is given for reference.

ticular, there is a $5 \mathrm{~m}$ short-wavelength geoid low over the Hjort trench (compare Figs. 4 and 9). Although the Hjort trench may have originated as a fracture zone trough, the current structure and/or stress state of the lithosphere is different from the lithospheric state of the Romanche trough. This observation suggests that the Hjort trench is not a purely strike-slip plate boundary. Thus, we will now focus on the comparison of the Hjort trench and Aleutian-Komandorski geoid signatures.

The ascending geoid profiles that cross the northern Hjort trench show the characteristic short-wavelength subduction zone geoid anomaly, i.e., an outer-rise high followed by a sharp low and then a sharp high with a peak-to-trough distance of $\sim 200 \mathrm{~km}$ (compare to Aleutian profile [2]). This short-wavelength geoid character suggests recent subduction activity at the Hjort trench. However, the northern Hjort trench peak-to-trough amplitude is $7 \mathrm{~m}$ instead of $12 \mathrm{~m}$ as for the central Aleutians, and the long-wavelength geoid high is not obvious in the Hjort trench profiles. Given the current understanding of the subduction zone geoid anomaly, the minimal long-wavelength high over the Hjort trench indicates that the total mass anomaly of the subducted slab is smaller than for the central Aleutians. This interpretation is qualitatively consistent with the slow subduction of young lithosphere. Also, the slightly subdued short-wavelength geoid anomaly is indicative of reduced lithosphere flexure as compared to the Aleutians, again consistent with the slow subduction of young lithosphere (e.g., see McAdoo and Martin, 1984).

The transition in the Hjort trench geoid anomalies from north to south resembles the transition from the central Aleutians to Komandorski Island. There is a gap in the Aleutian island arc bathymetric high between the central Aleutians and Komandorski Island, with a corresponding lack of the sharp high in geoid profiles [14] through [78]. The same effect is seen in the Hjort trench profiles south of profile [250]. Also, the dominance of the outer-rise high, due to the Emperor seamount rise for the Aleutians and the young lithosphere for the Hjort trench, is similar. The sharp geoid low gradually diminishes in the southern Hjort trench until there is a fracture zone-type step in the southernmost geoid profile. This profile crosses the extension of the Hjort trench close to the spreading ridge segment.

We therefore assume that the Aleutian-Komandorski system is tectonically analogous to the Hjort trench, thereby implying oblique convergence along the Hjort trench. The continuous volcanic activity and intermediate-depth earthquakes terminate between profiles [2] and [14] in the Aleutians. The level of shallow seismicity also decreases between Aleutian profiles [2] and [14], although there is a cluster of activity at Komandorski Island. Of course, it is difficult to specify one point that divides oblique subduction from no 


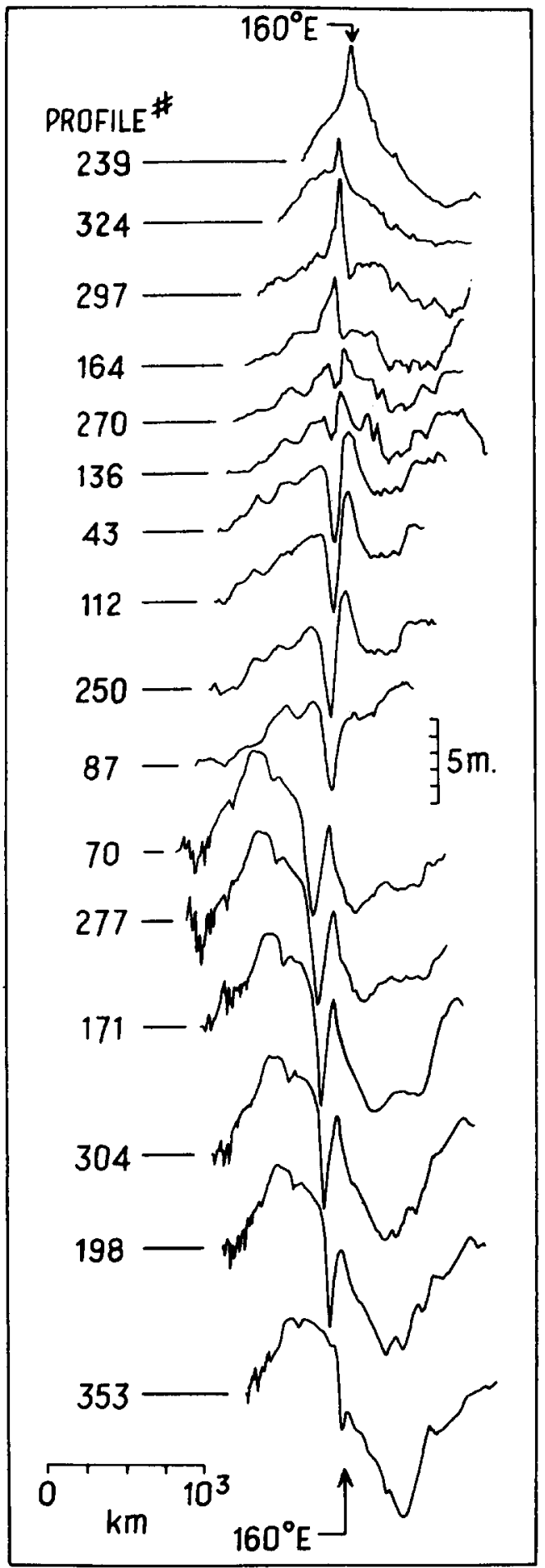

subduction, but certainly subduction is greatly diminished by Aleutian profile [14], which corresponds to Hjort trench profile [70]. Recall from Fig. 2 that the maximum length of missing crust occurs in the northern Hjort trench region. Thus, the hypothesis that this missing crust has been subducted at the Hjort trench is qualitatively supported by the transition in the geoid anomalies. To further corroborate this subduction hypothesis and prove that subduction is still occurring, it would be important to document a large underthrusting earthquake in the Hjort trench region.

\section{The large 1924 earthquake}

Although the missing crust in Fig. 2 might have been subducted at the Hjort trench, it is possible that the Hjort trench switched to a strike-slip boundary within the past few million years (anomaly 5 is $8-10 \mathrm{Ma}$ ). Three large earthquakes with $M>7$ have occurred along the Hjort trench (see Fig. 1). The focal mechanisms for the two recent earthquakes (1965 and 1970) are mostly strike-slip with one nodal plane aligned with the local strike of the Hjort trench; hence consistent with the RM2 plate motions. One of the largest magnitude earthquakes in the entire Macquarie Ridge complex is the June 26, 1924 event, which is located close to the 1965 event. Gutenberg and Richter (1949) assigned a magnitude of 7.8 to this earthquake, and the revised magnitudes from Abe (1981) were $\boldsymbol{M}_{\mathrm{s}}=7.7$ and $m_{\mathrm{B}}=7.9$. Since the largest earthquakes dominate the seismic energy release in a region, it is important to determine the focal mechanism of the 1924 event.

In general it is extremely difficult to deduce the first-motion focal mechanism of old earthquakes for a number of reasons: (1) the old records are lost or otherwise unavailable, (2) even if the records are collected, the polarity of the instruments is not known, and (3) the station distribution

Fig. 9. SEASAT geoid height profiles across the Hjort trench region. Left to right corresponds with west to east. The profiles are aligned so that constant longitude plots as a vertical line; $160^{\circ} \mathrm{E}$ is given for reference. Note that profiles [43], [112], and [250] display a subduction-type geoid anomaly. 


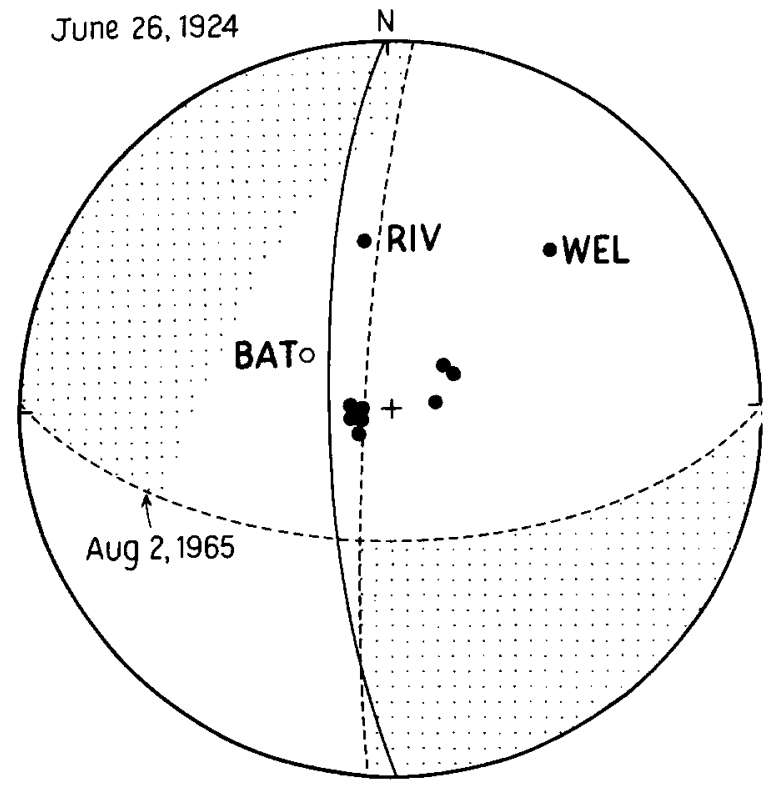

Fig. 10. Focal mechanism information for the June 26,1924 and August 2, 1965 earthquakes (lower-hemisphere equal-area projection). The first-motions are plotted for the 1924 event with solid dots representing compressional first-motions. Most arrivals are compressional and plot near the center of the focal plot, but there are three reliable points from close stations: compressional at Riverview (RIV) and Wellington (WEL), and dilatational at Batavia (BAT). These first-motions constrain one of the 1924 nodal planes (the solid line). The dotted lines show the focal mechanism solution for the 1965 event, with the dot pattern showing the compressional quadrants (from Banghar and Sykes, 1969). Although the second nodal plane for the 1924 event is poorly constrained (hence, it is not plotted); the 1924 focal mechanism is distinctly different from the 1965 focal mechanism.

affords poor coverage of the focal sphere. For the particular case of the 1924 earthquake, we are fortunate and thankful that Macelwane (1930) studied this earthquake. Since he collected the records within a few years after the event, Macelwane not only obtained many good-quality seismograms which he published as photographic reproductions, but he also corresponded with the various seismographic station operators to determine the polarity of the instruments. Consequently, a first-motion focal mechanism can be constructed from the information in Macelwane (1930). The problem of poor station distribution remains, but we can still reach an important con- clusion. Figure 10 plots the first-motion data compiled by Macelwane (1930). The North American and European stations are all compressional arrivals (mostly PKP), as is the P-wave at Wellington, New Zealand, and Riverview, Australia. There is one dilatational first-motion, which is based on clear arrivals from the two horizontal components at Batavia (Djakarta). Therefore, we can constrain one of the nodal planes: steeply dipping with a roughly north-south strike. We now compare this to the well-constrained focal mechanism for the 1965 event (see Fig. 10). The important point is that the first-motions for the 1924 event are incompatible with the 1965 focal mechanism. In fact, given the 1924 compressional first-motions in the 1965 northeast dilatational quadrant, it is not possible to force agreement with minor adjustments. Indeed, if the second nodal plane for the 1924 event is steeply dipping (such as the dashed plane in Fig. 10), then the strike-slip motion is opposite that of the 1965 event. Alternatively, the second nodal plane could be shallow dipping; the 1924 earthquake would then have a typical subduction zone underthrusting mechanism.

\section{Conclusions}

Three lines of evidence suggest subduction activity in the northern Hjort trench: (1) the missing crust as proposed by Weissel et al. (1977), (2) the comparison of geoid profiles from the Macquarie Ridge complex, Romanche trough, and Aleutian-Komandorski regions, and (3) the first-motion focal mechanism data for the large 1924 earthquake. Any one of these three components does not present compelling evidence for subduction; but taken together, the simplest interpretation is that the Hjort trench is an active subduction zone, with young lithosphere being subducted beneath the older lithosphere to the east. The level of seismic activity in the Hjort trench is certainly less than that of major subduction zones. However, by analogy with the Aleutian-Komandorski region, we would not expect a high level of seismicity in a strongly oblique subduction zone.

The geoid profiles over the Puysegur trench do not show a pronounced subduction zone anomaly, 
but this is consistent with a nascent subduction zone environment for the Puysegur trench region. Note that the current plate tectonic models predict that the Puysegur trench region would have a better developed subduction regime than the Hjort trench region, yet the geoid anomalies indicate the opposite. In conclusion, we propose that there is active subduction at the northern Hjort trench.

\section{Acknowledgments}

This research was partially supported by grants from the Shell Companies Foundation and the National Science Foundation to L.J. Ruff. We thank the organizers of the 1982 IUGG Mathematical Geophysics meeting at Bonas, France for providing a stimulating environment. Les Thurston drafted the figures, and Marie Schatz helped with the word processing.

\section{References}

Abe, K., 1981. Magnitudes of large shallow earthquakes from 1904 to 1980. Phys. Earth Planet. Inter., 27: 72-92.

Banghar, A.R. and Sykes, L.R., 1969. Focal mechanisms of earthquakes in the Indian Ocean and adjacent regions. J. Geophys. Res., 74: 632-649.

Cazenave, A., Lago, B. and Dominh, K., 1983. Thermal parameters of the oceanic lithosphere estimated from geoid height data. J. Geophys. Res., 88: 1105-1118.

Crough, S.T., 1979. Geoid anomalies across fracture zones and the thickness of the lithosphere. Earth Planet. Sci. Lett., 44: 224-230.

Davies, G.F., 1981. Regional compensation of subducted lithosphere: effects on geoid, gravity and topography from a preliminary model. Earth Planet. Sci. Lett., 54: 431-441.

Detrick, R.S., 1981. An analysis of geoid anomalies across the Mendocino fracture zone: implications for thermal models of the lithosphere, J. Geophys. Res., 86: 11751-11762.

Gutenberg, B. and Richter, C.F., 1949. Seismicity of the Earth. Princeton Univ. Press, Princeton, N.J., 273 pp.

Haxby, W.F. and Turcotte, D.L., 1978. On isostatic geoid anomalies. J. Geophys. Res., 83: 5473-5478.

Hayes, D.E., Talwani M. and Christoffel, D.A., 1972. The Macquarie Ridge complex. In: R.J. Adie (Editor), Antarctic Geology and Geophysics. Int. Un. Geol. Sci., Series B, No. 1, pp. 767-772.

Lazarewicz, A.R. and Schwank, D.C., 1982. Detection of uncharted seamounts using satellite altimetry. Geophys. Res. Lett., 9: 385-388.
Macelwane, J.B., 1930. The south Pacific earthquake of June 26, 1924. Beitr. Geophys., 28: 165-227.

Mammericks, J., Smith, S.M., Taylor, I.L. and Chase, T.E., 1975. Topography of the South Pacific. Scripps Institution of Oceanography.

Mc Adoo, D.C., 1981. Geoid anomalies in the vicinity of subduction zones. J. Geophys. Res., 86: 6073-6090.

Mc Adoo, D.C. and Martin, C.F., 1984. SEASAT observations of lithospheric flexure seaward of trenches. J. Geophys. Res., 89: 3201-3210.

Minster, J.B. and Jordan, T.H., 1978. Present-day plate motions. J. Geophys. Res., 83: 5331-5354.

Molnar, P., Atwater, T., Mammericks, J. and Smith, S.M., 1975. Magnetic anomalies, bathymetry, and the tectonic evolution of the South Pacific since the Late Cretaceous. Geophys. J.R. Astron. Soc., 40: 383-420.

Parsons, B. and Richter, F.M., 1980. A relation between the driving force and geoid anomaly associated with mid-ocean ridges. Earth Planet. Sci. Lett., 51: 445-450.

Ruff, L., Given J. and Sanders, C., 1982. The tectonics of the Macquarie Ridge, New Zealand: new evidence of strike-slip motion from the earthquake of May 25, 1981, $M_{\mathrm{w}}=7.7$. EOS Trans. Am. Geophys. Union., 63: 384 (Abstract).

Sailor, R.V. and Okal, E.A., 1983. Applications of SEASAT altimeter data in seismotectonic studies of the south-central Pacific. J. Geophys. Res., 88: 1572-1580.

Sandwell, D.T., 1984. A detailed view of the south Pacific geoid from satellite altimetry. J. Geophys. Res., 89: 1089-1104.

Sandwell, D. and Schubert G., 1980. Geoid height versus age for symmetric spreading ridges. J. Geophys. Res., 85: $7235-7241$.

Sandwell, D. and Schubert, G., 1982. Geoid height-age relation from SEASAT altimeter profiles across the Mendocino fracture zone. J. Geophys. Res., 87: 3949-3958.

Scholz, C.H., Reed, J.M.W., Weed, R.W. and Frohlich, C., 1973. Detailed seismicity of the Alpine fault zone and Fiordland region, New Zealand. Geol. Soc. Am. Bull., 84: 3297-3316.

Souriau, A., 1984. Geoid anomalies over Gorringe Ridge, North Atlantic Ocean. Earth Planet. Sci. Lett., 68: 101-114.

Sykes, L.R., Kisslinger, J.B., House, L.S., Davies, J.N. and Jacob, K.H., 1981. Rupture zones and repeat times of great earthquakes along the Alaska-Aleutian arc. In: D.W. Simpson and P.G. Richards (Editors), Earthquake Prediction: An International Review. 73-80, Am. Geophys. Union, Washington D.C.

Walcott, R.I., 1978. Present tectonics and Late Cenozoic evolution of New Zealand. Geophys. J.R. Astron. Soc., 52: 137-164.

Watts, A.B., 1979. On geoid heights derived from Geos-3 altimeter data along the Hawaiian-Emperor seamount chain. J. Geophys. Res., 84: 3817-3826.

Weissel, J.K., Hayes, D.E. and Herron, E.M., 1977. Plate tectonics synthesis: the displacements between Australia, New Zealand, and Antarctica since the Late Cretaceous. Mar. Geol., 25: 231-277. 